\title{
Prezentare a volumului
}

\author{
Gabriela Pană Dindelegan* \\ Facultatea de Litere, Universitatea din București, Str. Edgar Quinet 5-7, Sector 1, 010017 București, România \\ Institutul de Lingvistică „Iorgu Iordan - Al. Rosetti”, Calea 13 Septembrie 13, 050711 București, România
}

Numărul 6 din „Diacronia” (6/2017) include 12 studii de gramatică istorică a limbii române, reprezentînd contribuții ale membrilor Departamentului de Gramatică de la Institutul de Lingvistică „Iorgu Iordan - Al. Rosetti” al Academiei Române din București. Sînt studii de morfologie istorică, de sintaxă și de morfosintaxă istorică, dar și un studiu de formare a cuvintelor și interfața cu morfologia. Studiile continuă, pe de o parte, preocupări mai vechi ale Departamentului de Gramatică (vezi volumul The Syntax of Old Romanian (SOR), Oxford University Press, 2016,680 p.), iar, pe de altă parte, prezintă rezultate parțiale dintr-un studiu mai amplu asupra morfologiei istorice a limbii române, în curs de elaborare.

Ceea ce este comun tuturor articolelor este cercetarea bazată pe analiză de corpus. Autorii folosesc un corpus bogat și diversificat de limbă română veche (1521-1780), același cu cel utilizat pentru soR, preluînd, totodată, și criteriile de siglare folosite acolo (printre care amintesc completarea siglei cu anul de datare a textului; de exemplu: $\mathrm{CC}^{2} .1581$, Po.1582, A.1620, AD.1722-5). Comună este, de asemenea, legătura de conținut dintre articole, cu numeroase idei și concepte care circulă în mai multe articole (vezi ideea de stadii de 'gramaticalizare' și de 'gramaticalizare incompletă', de 'plural lexical', de 'plurifuncționalitate', de 'ambiguitate' și 'dezambiguizare', de 'variație diacronică' vs 'variație sincronică, de 'sintetism' vs 'analitism' etc.).

Cele mai importante obiective ale articolelor sînt:

(i) prezentarea originii, a datării, a localizării și a evoluției diverselor fenomene investigate;

(ii) examinarea diversificării valorilor sintactice și morfosintactice ale diverşilor formanți examinați și, implicit, dezambiguizarea unor forme plurifuncționale ale românei vechi;

(iii) urmărirea fenomenului de gramaticalizare, cu diversele lui ipostaze și etape;

(iv) examinarea particularităților de construcție și flexionare ale limbii vechi, cu evidențierea unor rezultate noi sau parțial noi în raport cu datele anterioare din bibliografie;

(v) urmărirea expresă a variației diacronice (de formă, de construcție, de topică, de valoare funcțională), variație care semnalează domenii ale limbii în plină mișcare și evoluție, prefigurînd importante schimbări lingvistice.

Revista include și o editare de text vechi, realizată de Alexandru Nicolae. Autorul îşi propune reeditarea unui text extrem de important din istoria lingvisticii românești; este vorba de textul aparținînd lui B.P. Hasdeu intitulat Principie de linguistică, text datînd din 1881, dar care impresionează și astăzi prin valoarea și modernitatea ideilor conținute. Textul este important și pentru istoria terminologiei lingvistice românești, incluzînd concepte și termenii corespunzători caracteristici epocii (fie împrumutați și adaptaţi tiparelor flexionare autohtone, fie creați în interiorul limbii); și sub acest aspect, textul lui Hasdeu impresionează prin modernitatea terminologiei lingvistice utilizate.

Sub aspectul conținutului, semnalăm, pentru domeniul morfologiei şi al interfeței morfologiefonologie, studiile: Auxiliarul de perfect compus o din graiul moldovenesc. Diacronie și sincronie; Substantive masive și abstracte pluralizate în limba veche; Ipostaze morfologice ale formei veri în (daco)româna veche; Auxiliarul condiționalului românesc: argumente semantice și funcționale în reconstituirea unui proces de gramaticalizare controversat. Pentru domeniul sintaxei și al relației sintaxă-semantică, indicăm: Note asupra unor realizări ale obiectului direct în limba veche; Construcții comparative in limba română veche;

\footnotetext{
*Adresă de corespondență: g_dindele@yahoo.com.
} 
Construcții (pseudo)scindate în româna veche. Pentru morfosintaxă, se disting titlurile: Particularități morfosintactice ale indefinitului tot în limba română veche; Particularități ale cuantificatorilor numelui în româna veche; Evoluția descendenților lui ipse în limba română. Pentru formarea cuvintelor și interfața cu morfologia, cităm articolul Desinența de plural -le și interferențe între morfologia flexionară și cea derivațională. Unul dintre articole privește domeniul pragmatic și relația lui cu gramatica: Interjecția in texte vechi românești.

După cum se vede, cuprinsul volumului este bogat și diversificat. Ca rezultate ale cercetărilor, autorii propun, adesea, observații noi (mai ample sau mai de detaliu) de descriere, dar și modificări, nuanțări, precizări ale interpretărilor anterioare, astfel că volumul merită întreaga atenție din partea cercetătorilor. 